\title{
1 Badnaviruses of sweetpotato: symptomless co-inhabitants on a global scale
}

2 Jan F. Kreuze*, Ana Perez, Marco Galvez ${ }^{\mathrm{a}}$, Wilmer J. Cuellar ${ }^{\mathrm{b}}$

4 Virology laboratory, International Potato Center (CIP), Lima, Peru

6 Running head: sweetpotato badnaviruses on a global scale

$8 \quad{ }^{\# a}$ Current address: USDA-APHIS-PPQ-S\&T-Center for Plant Health Science \&

9 Technology, Beltsville, MD, USA;

$10 \quad$ \#b Current address: International Center for Tropical Agriculture (CIAT), Cali, Colombia

11

$12 *$ Corresponding author

13 E-mail: j.kreuze@cgiar.org

14

15 JFK and AP contributed equally to this work. 


\section{Abstract}

18 Sweetpotato is among the most important root-crops worldwide, particularly in

19 developing countries, and its production is affected severely by a variety of virus

20 diseases. During the last decade a number of new viruses have been discovered in

21 sweetpotatoes from different continents through next generation sequencing studies,

22 among them belonging to the genus Badnavirus and collectively assigned to the species

23 Sweet potato pakkakuy virus (SPPV). We determined the complete genome sequence of

24 two SPPV isolates and show the ubiquitous presence of similar viruses in germplasm and

25 field material from around the globe. We show SPPV is not integrated into the

26 sweetpotato genome, occurs only at extremely low titers but is nevertheless efficiently

27 transmitted through seeds and cuttings. They are unaffected by virus elimination therapy

28 and lack any discernible symptoms in sweetpotatoes or indicator host plants.

29 Nevertheless, they show considerable variation in their nucleotide sequences and

30 correspond to several genetic lineages. Studies of their interaction with the two most

31 important sweetpotato viruses showed only limited synergistic increase in the titres of

32 one of two SPPV isolates. We contend that these viruses may pose little threat to

33 sweetpotato production and more likely represent a new type of persistent virus in a

34 possibly commensal or mutualistic relationship with sweetpotato.

36 Importance

37 Next generation sequencing approaches have in the last few years led to the discovery of

38 many virus like sequences in different crop plants including sweetpotatoes. The

39 significance of such discoveries can sometimes be elusive when they have not been 
40 associated with specific symptoms due to mixed infections or have been found in

41 apparently healthy plants. Badnavirus sequences found in sweetpotatoes provide a typical

42 case. Considering they have now been reported globally, it was important to determine

43 how common these viruses are and what their possible impact may be on sweetpotato

44 production. The significance of our research lies in resolving the case of badnaviruses,

45 providing evidence they represent a new type of vertically transmitted persistent and

46 apparently harmless episomal viruses living in a state of commensalism with their host. 


\section{Introduction}

49 Sweetpotato is one of the most important foodcrops worldwide, particularily in

50 developing countries, where it serves as a food security crop, animal feed as well as for

51 processing. Currently orange fleshed varieties are being promoted in sub-Saharan Africa

52 to combat vitamin A deficiency due to their high content of pro-vitamin A. Being

53 clonally propagated, sweetpotatoes suffer from the accumulation of viral diseases over

54 generations, leading to reduced yields. More than 30 viruses have been reported from

55 sweetpotato to date, with most of them belonging to the families Potyviridae,

56 Geminiviridae and Caulimoviridae (1). The most important among the sweetpotato

57 viruses is probably sweet potato chlorotic stunt virus (SPCSV; genus Crininvirus, family

58 Closteroviridae), as it is able to compromise resistance of sweetpotato to other viruses

59 causing synergistic viral diseases co-infection (2-8). The most important synergistic

60 disease is caused by co-infection of SPCSV and sweet potato feathery mottle virus

61 (SPFMV; genus Potyvirus, family Potyviridae) and may be exacerbated by infection with

62 additional viruses $(7,8)$.

63 Some of the more recently discovered viruses in sweetpotato are sweet potato badnavirus

64 A and B ((9), which have collectively been assigned to the species Sweet potato pakkakuy

65 virus (SPPV, family Caulimoviridae, genus Badnavirus). Although SPPV have already

66 been identified on all continents using various methods (10-14), little is still known about

67 the biology of this group of viruses. Badnaviruses (15) infect a broad range of important

68 crops including monocots and dicots, although most species have a limited host-range.

69 They often infect perennial corps and symptoms are mostly moderate to mild and can

70 sometimes be completely absent. Thus they are easily spread long distances through 
71 vegetative planting materials, although efficient seed transmission is also known for some

72 species. Horizontal transmission has been reported by various mealybug or aphid species

73 depending on the virus species. Some pararetroviruses, including some badnaviruses, can

74 be present as integrated sequences in the genomes of some host plants termed

75 endogenous para-retroviruses (EPRVs). Whereas such sequences are often fragmented

76 and unable to reconstitute an infective viral genome, some EPRVs can be reactivated by

77 certain stress conditions and form actively replicating viruses, a situation that occurs e.g.

78 with certain Banana streak viruses in some bananas (16). Integration takes place through

79 illegitimate recombination and is not necessarily associated with infection by a

80 replicating virus. Southern blot analysis, immune-capture RT-PCR and rolling circle

81 amplification are some of the techniques that have been employed to distinguish EPRVs

82 from episomal viruses.

83 The aim of our study was to investigate in more detail some aspects of SPPV infecting

84 sweetpotatoes, including its complete genome structure, how common it is, if SPPV like

85 sequences can be found integrated into the host genome, if it can be transmitted to other

86 plants, and if it is synergized by the SPCSV and or SPFMV.

\section{Results}

90 SPPV viruses are highly variable and ubiquitous among sweetpotato accessions

91 Entire genome sequences of sweetpotato pakakuy virus variants A and B were completed

92 and found to be 7380 and 7961 nt in length respectively. There genomic structure was

93 very similar to that typical of Badnaviruses, except that ORF3 was separated into two 
94 halves, which we designated ORF3a and ORF3b. They contain the movement (MP) and

95 coat protein (CP) domains, or the asparyl protease, reverse transcriptase (RT) and

$96 \mathrm{RNaseH}(\mathrm{RH})$ domains respectively and are separated by a short non-coding region. This

97 region is highly variable between the viruses and was sequenced several times from

98 independently amplified and cloned PCR products to ensure accuracy. For both viruses

99 ORF3b is extended prior to the first methionine codon to overlap partially with ORF3a

100 (12 and $21 \mathrm{nt}$ respectively in SPPV-A and SPPV-B) and is found in a +1 reading frame as

101 compared to ORF3a. SPPV-A and B share 79.5\% nt identity over the complete genome

102 and shared the same tRNA-met like region (TGG TAT CAG AGC GAG TAT) followed

103 by a short stem-loop (GGC AGG CTA AGC CTA CC) and a putative leader sequence

104 with extensive secondary structure (Fig 1).

105 To determine how common these badnaviruses were among sweetpotato germplasm, we

106 screened a collection of 78 sweetpotato genotypes from diverse geographic regions

107 available in CIP's germplasm collection with primers specific to SPPV-A and -B (Table

108 1) and found that many genotypes were infected by at least one of these viruses (Table 2).

109 Subsequent siRNA deep sequencing and assembly of bulked RNA extracts which

110 included samples recently received from Africa, produced additional contigs

111 corresponding to badnaviruses, some of which were clearly distinct from SPPV-A and

112 SPPV-B (S1 Data). Based on alignments of the RT and RH domains of the various

113 sequences obtained, degenerate primers were designed and used to amplify the

114 corresponding region from a subset of the 78 sweetpotato accession but also including 5

115 samples from African germplasm (Table 2). Phylogenetic analysis of alignments of nt or

116 aa sequences of the RT or RT-RH domains resulted in a phylogenetic tree with three 
117 distinct and strongly supported clades, irrespective of the evolutionary inference method

118 used, and a third more variable group, with less consistent support between phylogenetic

119 inference method and/or nt substitution model applied (not shown). Two of the clades

120 corresponded to SPPV-A and B, whereas the new clades were designated C and D (Fig

121 2). Whereas clades A-C were rather homogenous with mean within group nt variation of

$1221.1-2.2 \%$, clade D was more variable with a mean variability of $10.5 \%$ and identifiable

123 sub-groupings. Inclusion of additional sequences corresponding to SPPV from the

124 GenBank did not affect the grouping into these clades (data not shown).

126 Table 1. List of primers used in the detection for SPPV and qRT-PCR

\begin{tabular}{|c|c|c|c|}
\hline Target virus & Primers $^{\mathrm{a}}$ & Sequence $^{\mathrm{b}}\left(5^{\prime}-3^{\prime}\right)$ & Size $(\mathbf{b p})$ \\
\hline \multirow[t]{6}{*}{ SPPV A } & Spbadna 2 5200-F & AATAATCCТСТССТТCACTGGACAGAT & 600 \\
\hline & Spbadna $15800-\mathrm{R}$ & GATCCTCATGCTCTTCTTCAT & \\
\hline & SPBadna2 $3150 \mathrm{~F}$ & CAАCTACACTGAACCATATGTCTCTC & 400 \\
\hline & SPBadna1 3550R & AGTACCAAGGTCACCCGGCAC & \\
\hline & SPBadna2 $1750 \mathrm{~F}$ & TCGAGGAATGGTAGGAAGATTATC & 1400 \\
\hline & SPBadna2 $3150 \mathrm{R}$ & GAGAGACATATGGTTCAGTGTAGTTG & \\
\hline \multirow[t]{10}{*}{ SPPV B } & Spbadna 1 5200-F & AGG TGG AAT GCA CGC TCA GGA & 600 \\
\hline & Spbadna $25800-\mathrm{R}$ & TTAAATGTTGCTCATGGTCCTCTTCTG & \\
\hline & SPBadna1 3150F & СТАСААСТСТСААССАТАТGТСССТС & 400 \\
\hline & SPBadna2 $3550 \mathrm{R}$ & TGGAACCAAGATCAAGGAAGAA & \\
\hline & SPBadna2 3550F & TGGAACCAAGATCAAGGAAGAA & 1050 \\
\hline & SPBadna 4600R & TCCTGATGCCGATGATATGATCTG & \\
\hline & SPBadna 2700f & GAGAAGTTCAACGACAAGAAAGGAG & 500 \\
\hline & SPBadna2 3150r & GAGAGACATATGGTTCAGTGTAGTTG & \\
\hline & SPbadnaB 5704f & AGGTGGAATGCACGCTCAGGATTA & $600 \mathrm{bp}$ \\
\hline & SPbadnaB 6262r & AATGTTGCTCATGGTCCTCTTCTG & \\
\hline \multirow[t]{2}{*}{ SPPV RT } & Pakakuy RT-F & CARGAYCCICCICTGAAGCATGT & 700 \\
\hline & Pakakuy RT- R & CCTARCCAMGATCTTARCCCTTTCTT & \\
\hline \multirow[t]{2}{*}{ SPPV RH } & Pakakuy RT-F & CARGAYCCICCICTGAAGCATGT & 900 \\
\hline & Pakakuy RH-R & CCCAWCCWTCCATRCANCCRTC & \\
\hline \multirow[t]{2}{*}{ Begomovirus } & SPG1 $\mathrm{F}^{\mathrm{c}}$ & CCCCKGTGCGWRAATCCAT & 920 \\
\hline & $\mathrm{SPG} 2 \mathrm{~F}^{\mathrm{c}}$ & ATCCVAAYWTYCAGGGAGCTAA & \\
\hline SPFMV & SPF-F ${ }^{d}$ & GGATTAYGGTGTTGACGACACA & 589 \\
\hline SPVG & SPG-F ${ }^{d}$ & GTATGAAGACTCTCTGACAAATTTTG & 1191 \\
\hline SPVC & SPC-F $F^{d}$ & GTGAGAAAYCTATGCGCTCTGTT & 836 \\
\hline SPFCG2 & SPFCG2R $^{\mathrm{d}}$ & TCGGGACTGAARGAYACGAATTTAA & \\
\hline \multirow[t]{2}{*}{ SPPV-A } & rt-badA-left* & CCAACCCTCCTATGCACCT & 61 \\
\hline & rt-badA-right ${ }^{*}$ & AGTCGGGGGTCCACTTATCT & \\
\hline \multirow[t]{2}{*}{ SPPV-B } & rt-badB-left ${ }^{*}$ & TCGGCAGTAACAGACTACTTGG & 147 \\
\hline & rt-badB-right ${ }^{*}$ & TCTGCTTATCATCTCCGTTGG & \\
\hline
\end{tabular}


bioRxiv preprint doi: https://doi.org/10.1101/140517; this version posted May 21, 2017. The copyright holder for this preprint (which was not certified by peer review) is the author/funder, who has granted bioRxiv a license to display the preprint in perpetuity. It is made available under aCC-BY-NC 4.0 International license.

\begin{tabular}{lllc}
\hline Sweetpotato & rt-swt-actin-left & TTC TCC TTT CTA ACA CTC CTC AG & 60 \\
Actin & rt-swt-actin-right & CGC CTC GCT CTC TCT AGA TCC & \\
Cox gene & COX - F $^{*}$ & CGTCGCATTCCAGATTATCCA & 57 \\
& COX- R $^{*}$ & AACTACGGATATATAAGAGCCAAAACTG & \\
\hline
\end{tabular}

127

$128{ }^{a} \mathrm{~F}$, forward sense primer; $\mathrm{R}$, reverse antisense primer.

129 b Y: C or T; M: A or C; R: A or G; W: A or T; I: Inosine

$130{ }^{\mathrm{c}}$ Primers reported by (17)

131 ' Primers reported by (18)

132 * primers used for qRT-PC

133

134 
135 Table 2. List of accessions used in this study and results of PCR tests for specific 136 regions of SPPV-A and -B and degenerate primers.

\begin{tabular}{|c|c|c|c|c|c|c|c|c|c|c|c|c|}
\hline \multirow{2}{*}{$\begin{array}{l}\text { Accession } \\
\text { Number }\end{array}$} & \multirow[t]{2}{*}{ Accession Name } & \multirow[t]{2}{*}{ origin } & \multicolumn{3}{|c|}{ SPPV A } & \multicolumn{3}{|c|}{ SPPV B } & & \multirow[t]{2}{*}{ RT } & \multirow[t]{2}{*}{ RH } & \multirow[t]{2}{*}{ Control } \\
\hline & & & 1 & 2 & 3 & 1 & 2 & 3 & 4 & & & \\
\hline 400171 & Amarillo & BOLIVIA & & - & - & - & - & & & + & + & + \\
\hline 440034 & Mohc & BURUNDI & - & - & - & - & + & - & - & & & + \\
\hline 440294 & Totokoitu & COOK ISLANDS & - & - & - & + & - & + & - & & & + \\
\hline 400450 & Bogotana & COLOMBIA & - & + & - & - & - & - & - & + & + & + \\
\hline 440205 & Unknown & CHINA & - & + & - & - & - & - & - & + & + & + \\
\hline 440024 & Yanshu 1 & CHINA & - & - & + & + & + & + & + & & + & + \\
\hline 400584 & Bonito & CUBA & + & + & - & - & - & - & - & & & + \\
\hline 400632 & Santiaguero & CUBA & + & - & + & + & + & + & - & & & + \\
\hline 400822 & Canabacoa & DOMINICAN REPUBLIC & - & - & - & - & - & - & - & + & + & + \\
\hline 400830 & Hoja de Panamacho & DOMINICAN REPUBLIC & - & - & - & - & - & - & - & + & + & + \\
\hline 400028 & Violaceo (Puerto Rico) & DOMINICAN REPUBLIC & - & - & + & + & + & + & - & & & + \\
\hline 400034 & Unknown & DOMINICAN REPUBLIC & & - & - & - & - & & & + & + & + \\
\hline 400002 & Morado & ECUADOR & - & - & + & + & + & - & - & & & + \\
\hline 441729 & Blanco Ecuatoriano & ECUADOR & - & + & + & + & + & + & - & & & + \\
\hline 401111 & Camote Morado & GUATAMALA & - & - & - & - & - & - & - & - & + & + \\
\hline 401104 & Camote Naranja & GUATAMALA & - & - & - & - & - & - & - & + & + & + \\
\hline 401055 & Camote Blanco & GUATAMALA & & - & - & + & + & & & & & + \\
\hline 400023 & Colombia. 633 & GUATAMALA & - & - & - & - & - & - & - & & & + \\
\hline 401152 & Rojo & HONDURAS & & - & - & - & - & & & + & + & + \\
\hline 401154 & Unknown & HONDURAS & - & - & - & - & & - & - & + & + & + \\
\hline 440283 & BIS 50 & INDONESIA & - & + & + & + & + & - & + & & & + \\
\hline 440214 & BIS 99 & INDONESIA & - & - & - & - & - & - & - & & & + \\
\hline 401169 & Herbie & JAMAICA & - & - & - & - & & - & - & + & + & + \\
\hline 440116 & Gokoku-imo & JAPAN & - & - & + & + & + & - & - & + & & + \\
\hline 440295 & Seranggoon & MALASIA & & - & + & + & + & & & + & + & + \\
\hline 401212 & Regional de Tehuantepec & MEXICO & - & - & - & - & - & - & - & + & + & + \\
\hline 401215 & Coleccion Tierra Blanca & MEXICO & - & - & - & - & + & - & - & & & + \\
\hline 441724 & Cuitzeo & MEXICO & - & - & + & + & + & + & - & & & + \\
\hline 400010 & 226 & MEXICO & - & - & - & - & & - & - & & & + \\
\hline 440398 & 500 (PI 308201) & NEW ZEALAND & + & - & - & - & + & - & - & & & + \\
\hline 401223 & Cubano & NICARAGUA & - & - & - & - & & - & - & + & + & + \\
\hline 401224 & Camote & NICARAGUA & - & - & - & - & & - & - & + & + & + \\
\hline 401225 & Camote & NICARAGUA & - & - & - & - & - & - & - & + & + & + \\
\hline 401226 & $\mathrm{C}-15$ & NICARAGUA & - & - & + & + & + & + & - & & + & + \\
\hline 401227 & CEMSA-74-228 & NICARAGUA & - & - & + & + & + & + & + & & & + \\
\hline 401228 & Batata Morada & NICARAGUA & - & + & + & + & & + & - & & & + \\
\hline 401243 & Amarilla & PANAMA & - & - & - & - & - & - & - & + & + & + \\
\hline 401248 & Amarillo & PANAMA & - & - & - & - & + & - & + & & & + \\
\hline 401253 & Camote & PANAMA & - & - & + & + & & + & - & & + & + \\
\hline 440129 & Ma'alua & PAPUA NEW GUINEA & - & - & + & + & + & - & - & + & + & + \\
\hline 440305 & Tawa-1 & PAPUA NEW GUINEA & - & & + & + & + & - & - & + & + & + \\
\hline 400030 & Brasilera & PARAGUAY & - & - & - & - & - & - & - & & & + \\
\hline 400032 & Yety Aba & PARAGUAY & & - & + & - & - & & & & & + \\
\hline 420509 & Camote Amarillo & PERU & - & - & - & + & + & - & - & + & + & + \\
\hline 420617 & Chilpo Blanco & PERU & - & - & - & + & + & - & - & & & + \\
\hline 420065 & Huachano & PERU & + & + & + & + & + & + & + & + & & + \\
\hline
\end{tabular}


bioRxiv preprint doi: https://doi.org/10.1101/140517; this version posted May 21, 2017. The copyright holder for this preprint (which was not certified by peer review) is the author/funder, who has granted bioRxiv a license to display the preprint in perpetuity. It is made available under aCC-BY-NC 4.0 International license.

\begin{tabular}{|c|c|c|c|c|c|c|c|c|c|c|c|c|}
\hline 440160 & Philippine & PHILIPPINES & - & - & + & + & + & + & - & + & + & + \\
\hline 440052 & Margarita (SPV 70) & PUERTO RICO & - & - & + & + & + & + & - & + & + & + \\
\hline 440163 & MUgandae & RWANDA & - & - & - & + & + & - & - & & & + \\
\hline 440202 & Ngiriare (ACC 275) & SLB & - & + & + & + & + & + & + & & & + \\
\hline 440360 & Iqui (ACC 78) & SLB & & - & - & + & - & & & & & + \\
\hline 441169 & So 272 & SLB & - & - & - & - & - & - & - & + & + & + \\
\hline 400025 & LOVERs NAME & St Vincent \& Grenadines & - & - & - & - & + & - & - & & & + \\
\hline 440197 & Man Sai Daeng & THAILAND & - & - & - & - & - & - & - & + & + & + \\
\hline 440343 & Unknown & THAILAND & - & - & - & + & + & + & - & & & + \\
\hline 440348 & Kao & THAILAND & & & + & + & + & & & & & + \\
\hline 440274 & Kaloti & TONGA & - & - & - & + & + & - & - & + & + & + \\
\hline 440277 & Siale & TONGA & - & - & - & + & + & + & + & & & + \\
\hline 440012 & W - 217 & USA & - & - & - & - & - & - & - & & & + \\
\hline 440011 & W - 216 & USA & - & - & + & + & + & - & - & + & + & + \\
\hline 440132 & Beauregard & USA & & & & & & & & + & + & \\
\hline 401403 & Morado & VENEZUELA & - & - & - & - & & - & - & + & + & + \\
\hline 401396 & unknown & VENEZUELA & & - & - & - & + & - & - & & & + \\
\hline 441726 & Tacarigua & VENEZUELA & + & - & - & - & - & - & - & & & + \\
\hline 400020 & No 2743 & VENEZUELA & & - & - & + & + & - & - & & & + \\
\hline 440267 & Hung Loc 4 & VIETNAM & - & - & - & - & - & - & - & & & + \\
\hline 440145 & CAMEROUN 1112 & CAMEROUN & + & + & + & + & + & + & - & + & + & + \\
\hline 440146 & CAMEROUN 1592 & CAMEROUN & - & + & + & + & + & + & + & & + & + \\
\hline 440143 & CMR 048 & CAMEROUN & - & - & - & - & + & - & - & & & + \\
\hline 440144 & CMR 502 & CAMEROUN & + & - & - & - & - & - & - & + & + & + \\
\hline 440390 & TIS $87 / 0087$ & NIGERIA & - & - & + & + & + & + & - & & & + \\
\hline 440165 & Kawogo & UGANDA & - & - & + & + & + & + & - & & + & + \\
\hline 440166 & Tanzania & UGANDA & - & - & + & + & + & + & - & + & + & + \\
\hline field & Bitambi & UGANDA & & & & & & & & + & + & \\
\hline field & KSR675 NORAII & UGANDA & & & & & & & & + & + & \\
\hline field & KSR675 Kameri Ikumi & UGANDA & & & & & & & & + & + & \\
\hline field & Marooko & UGANDA & & & & & & & & + & + & \\
\hline field & Carrot C & TANZANIA & & & & & & & & + & + & \\
\hline 460397 & Ipomoea tiliacea & NICARAGUA & - & - & + & + & + & + & - & & & + \\
\hline 107665.9 & Ipomoea trifida & PERU & & & & & & & & + & + & \\
\hline 107665.19 & Ipomoea trifida & PERU & & & & & & & & + & + & \\
\hline
\end{tabular}




\section{SPPV can be graft transmitted to indicator plants}

141 Grafting experiments from sweetpotato (cv 'Huachano' infected with SPPV-A and -B) to 142 sweetpotato (cvs 'Man Sai Deng' infected with SPPV-C and 'Amarilla' infected with 143 SPPV-D, but which were not infected by SPPV-A or B) and from sweetpotato to I. setosa 144 followed by PCR of the grafted plants resulted in positive reactions in some cases

145 (treatment 4, 5, 9 and 13 in Table 3) indicating that SPPVs could be transmitted through

146 this means although, apparently not with $100 \%$ efficiency, since in most cases only

147 SPPV-B was transmitted (treatment 4, 5 and 9 in Table 3), whereas neither virus was

148 transmitted to either sweetpotato cultivar when the source plant 'Huachano' was also

149 infected by SPFMV and SPCSV (treatment $10 \& 13$, Table 3). To ensure that the virus

150 detected in the graft inoculated I.setosa did not represent passively carried particles, the

151 PCR positive I.setosa plants were used to graft inoculate a second I.setosa, which

152 subsequently became PCR positive upon testing, except when the I.setosa was also

153 infected by SPFMV and SPCSV (treatment $6 \& 7$ respectively in Table 3 ). In none of the

154 cases were any visible symptoms discerned, except those of SPVD when the combination

155 of SPFMV + SPCSV was included in the treatment, which are extremely severe in

156 I.setosa. Cloning and sequencing of the PCR fragments from the serially inoculated 157 I.setosa plants, confirmed they were identical to the sequence in the originally grafted 158 plant in all cases.

159

160 Table 3. Results of graft transmission experiments

\begin{tabular}{lllcl}
\hline & & \multicolumn{3}{c}{ PCR results* } \\
Treatment & plants & SPPV-A & SPPV-B & RT \\
\hline
\end{tabular}




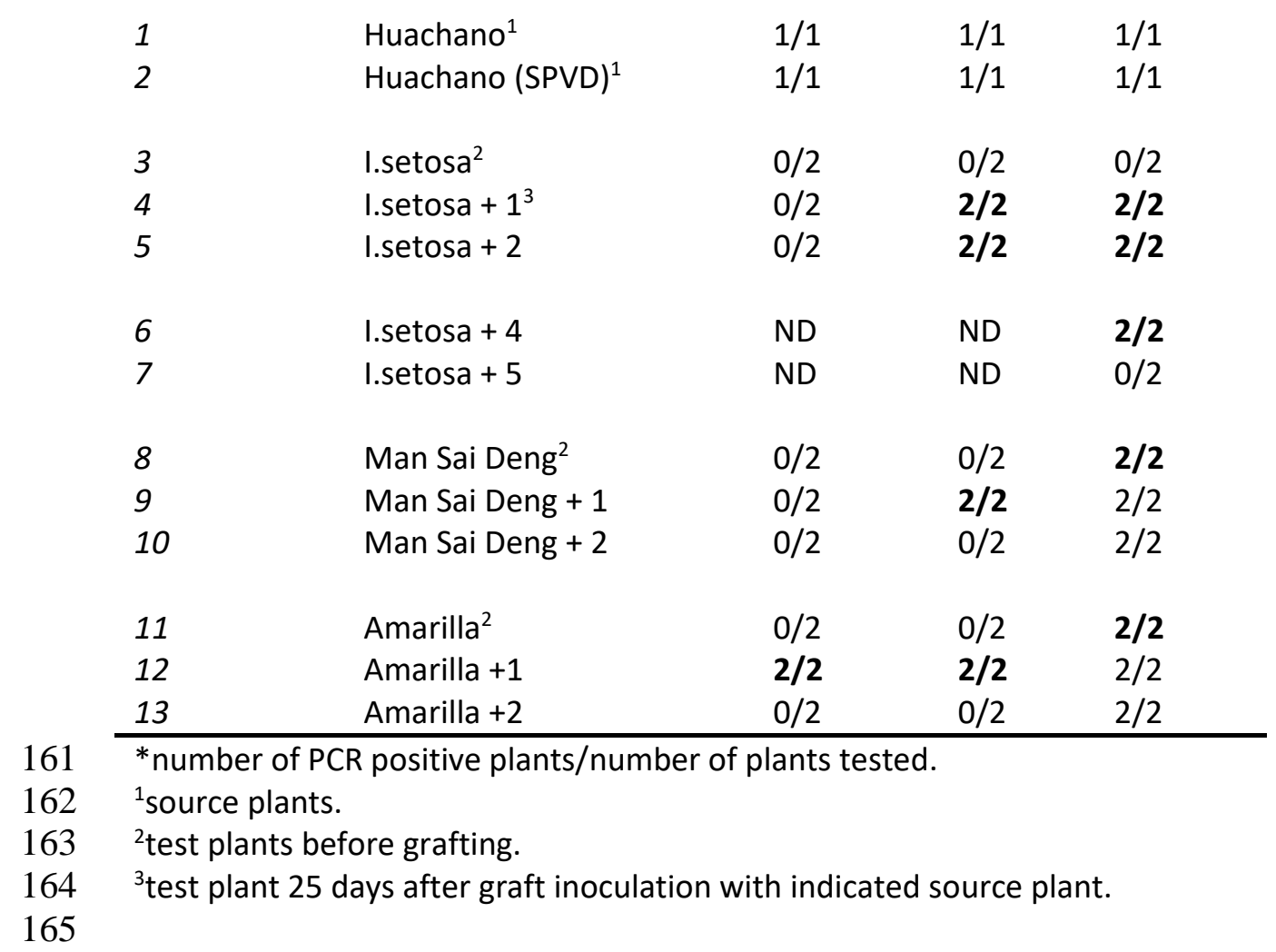

\section{SPPVs are seed transmitted in sweetpotato}

167 A previously generated in-vitro germinated population from a cross between the cultivars

168 Beauregard and Tanzania (19) which were both infected by SPPV (Table 2 \& 4) were

169 tested by PCR for presence SPPV in the established in-vitro plants and 76 out of 76 tested

170 plants were found to be positive. PCR fragments were sequenced from 'Beauregard' (the

171 mother), as well as three progenies and those of the progeny were found to be $>99 \%$

172 identical to those found in Beauregard, and which corresponded to SPPV-B. In contrast

173 all seedlings (203 plants) tested negative by PCR for begomoviruses, which both parents

174 were also infected with, and also were PCR negative for SPFMV, sweet potato virus G

175 (SPVG) and sweet potato virus C (SPVC), which were infecting the parent 'Beauregard'

176 (Table 4). Thus, SPPV was transmitted to seed at very high efficiency. 
178 Table 4. Results of PCR testing of in-vitro germinated seedlings and their parents

\begin{tabular}{l|lllll}
\hline Virus identified & SPPV & Begomovirus & SPVG & SPVC & SPFMV \\
\hline Beauregard & $1 / 1^{*}$ & $1 / 1$ & $1 / 1$ & $1 / 1$ & $1 / 1$ \\
Tanzania & $1 / 1$ & $1 / 1$ & $0 / 1$ & $0 / 1$ & $0 / 1$ \\
B x T seedlings & $76 / 76$ & $0 / 203$ & $0 / 203$ & $0 / 203$ & $0 / 203$ \\
\hline
\end{tabular}

\section{Viral titers of SPPV are less than one copy per cell}

182 Southern or dot-blot experiments using SPPV-A or -B specific chemi-luminiscent or

183 radioactive probes consistently failed to detect either virus in several sweetpotato

184 accessions tested irrespective if the plant was healthy, or infected by SPCSV, SPFMV or

185 both viruses (data not shown). On the other hand sweetpotato DNA spiked with plasmid

186 DNA containing the SPPV-A or -B probe fragments at a concentration corresponding to

187 one or half a copy per sweetpotato genome were readily detected in Southern blot (Fig 3),

188 indicating that the titers of these viruses must be well below these concentrations, and

189 simultaneously imply these viruses are not integrated into the genome.

192 SPPV titers are extremely low, are only minimally affected by co-infection of

193 SPCSV and SPFMV whereas corresponding siRNA change their size distribution

194 and are more abundant in SPVD affected plants

195 Because SPPV was below the detection limit of the Southern blot or dot-blot methods, a

196 quantitative real-time PCR assay was developed to evaluate the distribution of virus titres

197 in different leaves of sweetpotato cv Huachano. Results revealed qRT-PCR C(t) values

198 averaging around 6 cycles below those of the reference gene actin, indicating extremely 
199 low concentrations in the extracted leaves (i.e. $\sim 1 \%$ compared to actin). SPPV RNA

200 concentrations between different leaves on the same plant showed up to 6 fold

201 differences with the upper leaves tending to have higher titres (Fig 4). On the other hand,

202 when comparing relative expression levels of virus infected plants to those of healthy

203 plants, a significant increase of around 2.5 fold could be identified only for SPPV-B in

204 plants infected with both SPCSV and SPFMV (Fig 4). Mapping of siRNA sequences

205 determined from the three plants indicated that this correlated with increased siRNA

206 production corresponding to SPPV-B viruses in plants infected by SPFMV and SPCSV

207 as compared to other plants, mainly of $22 \mathrm{nt}$ size, whereas $24 \mathrm{nt}$ siRNAs were strongly

208 reduced. Whereas this effect could be appreciated also in SPPV-A, it was slightly less

209 extensively targeted by siRNAs than SPPV-B (Fig 5).

\section{Discussion}

212 Badnaviruses in sweetpotato remain somewhat enigmatic. SPPV was initially identified

213 through siRNA sequencing from apparently healthy plants thought to be virus free (9),

214 and has since then been identified in several NGS $(10,12,14)$ studies and by PCR using

215 specific primers based on the initial report $(11,13)$. Indeed, in this study we found that

216 every plant we tested eventually turned out PCR positive for SPPV when degenerate

217 primers were employed. However, results were not always consistent over time in all

218 plants, a plant could test positive for a leaf sample at one time and negative at others (data

219 not shown), suggesting low and unequally distributed concentrations in the plant.

220 Nevertheless, because some badnaviruses are known to exist as EPRVs and EPRVs are

221 also targeted by siRNAs through RNA silencing (16), it was important to confirm that 
222 what we were detecting were not integrated sequences. Our Southern blot experiments in

223 Huachano unequivocally show that SPPV is not integrated in the genome of at least that

224 cultivar and that SPPV concentrations are so low that they cannot even be detected by

225 chemiluminescent hybridization. This conclusion was supported by qRT-PCR results

226 showing that expression of SPPV RNA was around a hundred fold lower than that of the

227 Actin reference gene (and a $~ 500$ fold lower than COX reference). Sequence analysis of

228 some of the amplified fragments from plants originating from different parts of the world

229 showed considerable sequence variation between SPPV found in different genotypes, but

230 also that many genotypes were infected by more than one variant, just like we found in

231 cv. Huachano. This result suggests SPPV is an actively evolving virus.

232 Our virus transmission experiments also clearly showed SPPV-A and B could be

233 transmitted by grafting to I. setosa and other sweetpotato plants infected with SPPV-C or

234 D. It is noteworthy that in most cases only SPPV-B was transmitted, whereas qRT-PCR

235 results suggested titres of both viruses were very similar. Perhaps SPPV-B is more adept

236 at establishing infections than SPPV-A in a competitive situation. However the fact that

237 SPPV-A and -B were found together and that SPPV-B could be transmitted to plants

238 infected with SPPV-C or -D provided further evidence these viruses are not mutually

239 exclusive. On the other hand co-infection of the source plant with SPFMV and SPCSV

240 eliminated graft transmission of either virus to other sweetpotato plants, and serial

241 transmission to I. setosa. SPVD is a severe disease in sweetpotatoes and sometimes lethal

242 in I. setosa. It is conceivable that the stress caused by SPVD affects the formation of graft

243 unions and other physiological factors that may impede efficient transmission of a virus

244 already in such low titres. 
245 Qin (2016) reported graft transmission of SPPV-A to I. setosa as determined by PCR,

246 resulting in mosaic symptoms. However, it was not clear from that report if other viruses

247 were infecting the original sweetpotato plants, and mosaic is not a typical symptom

248 produced by badnaviruses. Indeed, this contrast with our findings which could identify no

249 symptoms in I. setosa after graft transmission. None of the plants tested in this study

250 showed any clear virus symptoms (except when affected by SPVD); the extremely low

251 virus titres determined by qRT-PCR in the accession Huachano, suggest only very few

252 cells might be infected and virus expression could be too low to induce any significant

253 physiological changes in the plant that might manifest themselves in symptoms.

254 However, without the availability of a plant lacking SPPV sequences it will remain

255 impossible to determine any biological impact SPPV may have on sweetpotato

256 production. Our qRT-PCR and siRNA sequencing experiment in plants co-infected with

257 SPFMV and SPCSV indicated only minor effects on SPPV titres, which were only

258 significant in the case SPBaV-B in dual infection with SPFMV and SPCSV. The modest

2592 fold increase observed, however, seems unlikely to be able to mediate much impact,

260 particularly when considering the several hundreds of fold increase of SPFMV caused by

261 SPCSV co-infection $(5,7,20)$. In contrast, as had been previously observed (9), infection

262 of both SPFMV and SPCSV had a marked effect on the amount and size of siRNAs

263 targeting SPPV, but also infection by SPFMV and SPCSV alone affected siRNA amounts

264 (but not size). These changes can probably be attributed to the effects of expression of the

265 different silencing suppressors of both viruses, but as evidenced from qRT-PCR

266 experiments, these nevertheless had minimal effect on SPPV titres themselves. 
268 The genomes organizations of the two SPPV isolates determined in this study are slightly

269 different from other badnaviruses in that ORF3 is divided into two ( $3 a$ and $3 b$ ), a

270 situation also found in cassava vein mosaic virus (genus Cavemovirus). Although ORF3b

271 may be expressed from a separate mRNA the possibility remains that it is expressed

272 through +1 ribosomal frameshifting as there is an overlap between the two ORFs when

273 extending ORF3b 5'of it's first potential initiation codon.

275 Because 'Huachano' plants originated from in-vitro plants that had been submitted to

276 thermotherapy and meristem tip culture for virus elimination, it suggests that despite its

277 low virus titers SPPV is able to maintain itself in meristematic tissues. Indeed, attempts in

278 other laboratories to eliminate viruses by thermotherapy and meristem excision failed to

279 eliminate SPPV (Christopher Clark, personal communication). On the other hand several

280 accessions of a wild sweetpotato relatives, I. tiliacea and I.setosa, which are grown from

281 seed, were also found to be positive suggesting that the virus could also be transmitted by

282 seed. Seed transmission was confirmed to be highly efficient in sweetpotato by testing in-

283 vitro germinated seedlings derived from a cross between 'Beauregard' and 'Tanzania',

284 whereas other viruses infecting either parent showed no evidence of seed transmission, as

285 expected. Perhaps this is the principal mechanism by which SPPV has maintained and

286 spread itself among sweetpotatoes worldwide as it seems hard to imagine any vector

287 could be very efficient at transmitting SPPV between sweetpotatoes when titres are so

288 low. On the other hand, the sequence variation found between different genotypes

289 indicates they are not all descending from the same source and it could be possible that

290 sweetpotato is occasionally (re-)infected from an unknown source plant. Electron 
291 microscopic studies by Sim et al.,(21) claimed to identify badnavirus like particles in

292 Ipomoea nil plants and it could be interesting to survey more wild Ipomoeas spp. as

293 possible sources of SPPV.

295 Based on their apparent universal presence in sweetpotatoes and lack of obvious

296 symptoms and vertical transmission over generations, SPPV could be considered among

297 the persistent (or criptic) viruses $(22,23)$. Previously identified persistent viruses have

298 been exclusively RNA viruses belonging to specific families like Partitiviridae \&

299 Totiviridae (dsRNA) or Endornaviridae (ss+RNA). Persistent viruses are characterized by

300 vertical transmission, from seed and or pollen and cell-to-cell by redistribution in

301 dividing cells; they lack movement proteins and in the case of endornaviruses even lack

302 any discernible proteins besides the replicase. Because they also lack any discernible

303 symptoms in infected plants they have been considered commensal or mutualistic in their

304 interaction with plants, although mutualistic interaction have only been proven in a

305 couple of cases $(24,25)$. Whether the presence of SPPV in all the genotypes we tested

306 may similarly results from a mutualistic interaction or even a process of human selection

307 remains to be determined but is certainly an intriguing possibility.

308

309 Materials and Methods

\section{$310 \quad$ Plant material and viruses}

311 Plant materials used are summarized in Table 1. A total 78 accessions from the

312 worldwide sweetpotato collection (including five newly acquired accessions not yet

313 assigned accession numbers) and three related wild Ipomoea spp. at the International 
314 potato center (CIP) genebank were evaluated by PCR for presence of SPPV. They were

315 established and maintained in an insect-proof greenhouse at $27 \pm 1^{\circ} \mathrm{C}$ at $\mathrm{CIP}$ as a backup to

316 the in-vitro collection since their original acquisition. cv 'Huachano' used in this study

317 originated from in-vitro 'virus free' plants that had passed through thermotherapy and

318 meristem tip culture (9). A mapping population of a cross between cv Beauregard and

319 Tanzania was described previously (19). Plants of the universal sweetpotato virus

320 indicator I. setosa and one accession of I. tiliacea were grown from seed produced at CIP

321 virology unit.

322

323 Nucleic acid extractions

324 Total DNA from infected Ipomoea spp. leaves was extracted using the CTAB method

325 (26). Leaf tissue (approximately 250-400mg) was ground to a fine power in liquid

326 nitrogen using a mortar and pestle, in the presence of $2 \mathrm{ml}$ of extraction buffer, followed

327 by an incubation period at $60^{\circ} \mathrm{C}$ for $30 \mathrm{~min}$ and addition of an equal volume of

328 chloroform: isoamyl alcohol (24:1). The homogenate was vigorously shaken at room

329 temperature for $10 \mathrm{~min}$ using a vortex and after centrifugation at $12000 \mathrm{~g}$ for $10 \mathrm{~min}$, the

330 supernatant $(\sim 500 \mathrm{ul})$ was recovered, mixed with same volume of Isopropanol and

331 centrifugated at $12000 \mathrm{~g}$ for $10 \mathrm{~min}$. The precipitated DNA was washed with $70 \%$

332 ethanol, dried, resuspended in $100 \mathrm{ul}$ of Nucleases free water (NFW), and kept at $-20^{\circ} \mathrm{C}$

333 until analysis.

334 Total RNA was extracted using CTAB RNA method modified with LiCl (Adapted from

335 (27)), from fresh leaves by grinding tissue with a hand roller, adding $10 \mathrm{x}(\mathrm{v} / \mathrm{w})$ of CTAB

336 buffer followed by centrifugation in a microfuge at maximum speed for 5 min at room 
337 temperature. Subsequently an equal volume chloroform IAA (24:1) was added and the

338 homogenate was mixed thoroughly before centrifuging again at maximum speed in a

339 microfuge for $5 \mathrm{~min}$. The supernatant was carefully removed and mixed with an equal

340 volume of $4 \mathrm{M} \mathrm{LiCl}$ and left overnight on ice in fridge. The precipitated RNA was

341 centrifuged for $20 \mathrm{~min}$ at maximum speed in a microfuge and washed with $70 \%$ ethanol,

342 the pellet was dried and kept at $-70^{\circ} \mathrm{C}$ until analysis.

\section{PCR amplifications, sequencing and sequence analysis}

345 PCR reactions were performed in a total volume of $25 \mathrm{ul}$ containing $2 \mathrm{mM} \mathrm{MgCl}_{2}, 1 \mathrm{X}$

346 PCR reaction buffer, $0.2 \mathrm{mM}$ dNTPs, $0.2 \mathrm{uM}$ of each primer, 0.02units Taq DNA

347 polymerase (Promega) and $1 \mathrm{ul}$ (100ng) of DNA sample. DNA from healthy I. setosa

348 plants was also included in these experiments as negative controls. PCR amplification of

349 virus specific fragments of SPPV-A and -B from cv Huachano, was performed using

350 primers designed based on previously reported partial sequences (9). Additional primers

351 were designed based on the conserved functional domains present in the putative

352 polyprotein encoded by open reading frame (ORF) 3 for detection SPPV-A and -B in

353 germplasm and grafting experiments (Table 2). PCR was performed in a DNA thermal

354 cycler (Applied Biosystems) with an initial denaturation cycle for 2 min at $94^{\circ} \mathrm{C}$,

355 followed by 35 cycles for 30 s at $94^{\circ} \mathrm{C}, 30$ s at $56^{\circ} \mathrm{C}, 1 \mathrm{~min}$ at $72^{\circ} \mathrm{C}$, and a final extension

356 for $10 \mathrm{~min}$ at $72^{\circ} \mathrm{C}$. The amplified products were loaded in a $1 \%$ agarose gel stained with

357 GelRed $^{\text {тм }}$ (Biotum). Amplified fragment were cloned into pGEM-T Easy (Promega).

358 Sequencing of PCR amplified fragments using the Sanger method was performed by

359 Macrogen (Seoul, Korea) 
360 Nucleic acid alignments and phylogenetic analysis were performed using Mega7 (28)

361 (www.megasoftware.net) using maximum likelihood and the substitution models

362 calculated to best fit the alignment data.

\section{Quantitative real-time PCR}

366 Sweetpotato plants were infected with SPFMV, SPCSV, both viruses under controlled

367 greenhouse conditions in Lima, Peru. Cuttings were taken from infected plants and grown

368 for 3 months after which leaves were collected from basal, middle and top of each plant.

369 Total RNA was extracted using CTAB as described above. $1 \mu \mathrm{g}$ of total RNA was treated

370 with $2 \mathrm{U}$ of Turbo DNA-free $e^{\mathrm{TM}}$ (Ambion) in a total volume of $10 \mu \mathrm{l}$ according to the

371 manufacturer's protocol. After heat deactivation of the DNase enzyme cDNA synthesis

372 was carried out using 1ul of the DNase treated RNA, random primers (Invitrogen) and

373 Superscript ${ }^{\mathrm{TM}}$ III reverse transcriptase (Invitrogen) in a total volume of $20 \mathrm{ul}$ according to

374 the manufacturer's protocol.

375 The qPCR primers were for actin, SPPV-A and -B (Table 1) were designed using the

376 "Primer3" open source bioinformatic tool (http://primer3.sourceforge.net/). Primers for

377 cytochrome oxidase (Cox) have been previously reported (29).

378 The qPCR experiment was set up with three replicates per sample per plate. The Power

379 SYBR $^{\circledR}$ Green PCR Master mix (Applied biosystems) was employed for the qPCR with 4

$380 \mu \mathrm{l}$ of cDNA solution in a volume of 10ul according to the manufacturer's protocol. The

381 reaction and the detection of the fluorescent signal were performed with the Mx 3005P

382 qPCR System (Stratagene). Actin and Cox genes were used as internal control and 
383 reference genes for data normalization. The data analysis was carried out using the $2^{(-\Delta \Delta C t)}$

384 method (30) to determine relative expression levels. The REST2009 software (Qiagen)

385 was used to determine statistical significances in relative expression between different

386 samples.

388 Southern blots

389 A plasmid containing SPPV insert was used to synthesize non-radioactive probe using the

390 PCR DIG Probe Synthesis Kit (Roche) with the primers SPbadnaB 5704f and SPbadnaB

391 6262r (Table 1) which amplified a 600 bp fragment of ORF $3 b$ region. The probe was

392 amplified with a thermal cycler (Piko, Finnzymes) using 30 cycles, each consisting of 30

$393 \mathrm{sec}$ at $95^{\circ} \mathrm{C}, 30 \mathrm{sec}$ at $60^{\circ} \mathrm{C}$ and $40 \mathrm{sec}$ at $72^{\circ} \mathrm{C}$. A final step of $7 \mathrm{~min}$ at $72^{\circ} \mathrm{C}$ also was

394 included. Total DNA from sweet potato cv. 'Huachano' foliar tissue was extracted using

395 CTAB method as described above. Extracted DNA (30ug) was digested with Ecor I and

396 separated by $0.8 \%$ agarose gel electrophoresis in TAE containing GelRed ${ }^{\mathrm{TM}}$ overnight at

397 30v. The plasmid containing the SPPV insert linearized with Pst I and used as a positive

398 control. After depurination, denaturation and neutralization steps, DNA was transferred

399 to a positively charged nylon membrane and fixed with ultraviolet light treatment (UV

400 Stratalinker 2400 Stratagene) DNA was then pre-hybridized, hybridized and developed

401 with CDP-Star, ready to use kit (Roche) following the manufacturer's procedures and

402 Kodak Biomax light film (Sigma).

403

404 Graft transmissions 
406 accession numbers 401243 and 440197 respectively) which tested negative for SPPV-A

407 or -B by PCR screening were selected for graft transmission experiments from cv

408 Huachano. Plants were tested by PCR for SPPV-A and B and generic SPPV primers

409 before graft inoculation, after which they were inoculated by side grafting a single node

410 including leaf of the sweetpotato cv Huachano which was either healthy, or affected by

411 SPVD. All plants were maintained in a greenhouse under controlled conditions at $27 \pm 1^{\circ}$

$412 \mathrm{C}$ and monitored for symptoms up to 8 weeks and tested by PCR at 25 days post grafting.

413 The success of the graft union was confirmed by survival of the grafted scion throughout

414 the experiment. PCR fragments amplified by SPPV-A and -B specific primers were

415 sequenced to corroborate the results. To confirm that positive PCR results in graft

416 inoculated I.setosa plants were not due to passive transmission of virus from the grafted

417 sweetpotato scion, serial transmission was performed by grafting scions from the first

418 I.setosa plants to two new I. setosa plants. The serially grafted I.setosa plants were tested

419 by PCR using the generic primers RT-F and RT-R at 21 days post inoculation.

\section{1 siRNA sequencing and assembly}

422 To evaluate effect of co-infection of SPFMV and SPCSV on SPPV siRNA levels, leaves

423 from the middle of 1 month old healthy, SPFMV, SPCSV or SPVD affected samples of

424 'Huachano' were used for RNA extraction. RNA was extracted using Trizol reagent

425 according to the manufacturers instructions. RNA was then run in a 3.5\% agarose gel and

426 the band corresponding to siRNAs cut and purified using quantum prep gel purification

427 columns (Bio-Rad). Purified siRNAs were sent to Fasteris Life Sciences (Switzerland) 
428 for sequencing on an Illumina Hiseq 2000. Small RNA sequences were downloaded and

429 are accessible

430 https://research.cip.cgiar.org/confluence/display/cpx/CIP.sweetpotato.2014, siRNA

431 sequences were mapped against the genomes of SPPV-A and SPPV-B using MAQ and

432 coverage of their respective genomes by siRNAs was visualized using a custom script

433 (available from authors upon request).

434 To identify SPPV infecting sweetpotato cultivars collected from the field in Africa, RNA

435 was extracted from leaves of seven different plants and combined with 13 additional

436 samples from potato and other plant species from and processed and sequenced as

437 described above (accessible from

438 https://research.cip.cgiar.org/confluence/display/cpx/GAF13-14), except that sequences

439 were de-novo assembled using velvet as described previously, and contigs were

440 submitted to BlastX at NCBI selecting Badnaviruses as organism search set. The hit

441 tables were downloaded and imported into Microsoft Excel for presentation (S1 Data),

442 and contigs with hits were aligned to SPPV-A and -B sequenced for design of degenerate

443 primers able to identify all SPPV variants.

445 Accession numbers

446 The complete genome sequences of SPPV-A and SPPV-B determined from 'Huachano'

447 were submitted to GenBank, receiving accession numbers FJ560945.1 and FJ560946.1

448 respectively. Partial sequences of the reverse transcriptase and/or RNaseH domains from

449 addition cultivars received GenBank accession numbers KM000051-KM000054,

450 KM009088-KM009100 \& KM015301-KM015304. 


\section{Acknowledgements}

453 We thank Segundo Fuentes, Dora Quispe, Genoveva Rossel and David Tay for support

454 and sharing of materials. We thank Jari Valkonen and Isabel Weinheimer for sharing 455 primer sequences for real-time PCR. 


\section{References}

458 1. Clark CA, Davis JA, Abad JA, Cuellar WJ, Fuentes S, Kreuze JF, Gibson RW,

459 Mukasa SB, Tugume AK, Tairo FD, Valkonen JPT. 2012. Sweetpotato Viruses: 15

$460 \quad$ Years of Progress on Understanding and Managing Complex Diseases. Plant Dis

$46196: 168-185$.

462 2. Cuellar WJ, Galvez M, Fuentes S, Tugume J, Kreuze J. 2015. Synergistic

463 interactions of begomoviruses with Sweet potato chlorotic stunt virus (genus

464 Crinivirus ) in sweet potato (Ipomoea batatas L.): Sweet potato begomovirus

465 synergism with SPCSV. Mol Plant Pathol 16:459-471.

466 3. Cuellar WJ, De Souza J, Barrantes I, Fuentes S, Kreuze JF. 2011. Distinct

467 cavemoviruses interact synergistically with sweet potato chlorotic stunt virus (genus

468 Crinivirus) in cultivated sweet potato. J Gen Virol 92:1233-1243.

469 4. Cuellar WJ, Kreuze JF, Rajamäki M-L, Cruzado KR, Untiveros M, Valkonen JPT.

470 2009. Elimination of antiviral defense by viral RNase III. PNAS 106:10354-10358.

471 5. Karyeija RF, Kreuze JF, Gibson RW, Valkonen JPT. 2000. Synergistic Interactions

472 of a Potyvirus and a Phloem-Limited Crinivirus in Sweet Potato Plants. Virology

$473 \quad 269: 26-36$.

474 6. Kreuze JF, Savenkov EI, Cuellar W, Li X, Valkonen JPT. 2005. Viral Class 1

475 RNase III involved in suppression of RNA silencing. J Virol 79:7227-7238. 
476 7. Mukasa SB, Rubaihayo PR, Valkonen JPT. 2006. Interactions between a crinivirus,

477 an ipomovirus and a potyvirus in coinfected sweetpotato plants. Plant Pathol

$478 \quad 55: 458-467$.

479 8. Untiveros M, Fuentes S, Salazar LF. 2007. Synergistic Interaction of Sweet potato

480 chlorotic stunt virus (Crinivirus) with Carla-, Cucumo-, Ipomo-, and Potyviruses

$481 \quad$ Infecting Sweet Potato. Plant Dis 91:669-676.

482 9. Kreuze JF, Pérez A, Untiveros M, Quispe D, Fuentes S, Barker I, Simon R. 2009.

483 Complete viral genome sequence and discovery of novel viruses by deep

484 sequencing of small RNAs: A generic method for diagnosis, discovery and

$485 \quad$ sequencing of viruses. Virology $388: 1-7$.

10. Kashif M, Pietilä S, Artola K, Jones RAC, Tugume AK, Mäkinen V, Valkonen JPT.

487 2012. Detection of Viruses in Sweetpotato from Honduras and Guatemala

488 Augmented by Deep-Sequencing of Small-RNAs. Plant Dis 96:1430-1437.

11. Mbanzibwa DR, Tairo F, Gwandu C, Kullaya A, Valkonen JPT. 2011. First Report of Sweetpotato symptomless virus 1 and Sweetpotato virus A in Sweetpotatoes in Tanzania. Plant Dis 95:224.

492 12. Mingot A, Valli A, Rodamilans B, San León D, Baulcombe DC, García JA, López-

493 Moya JJ. 2016. The P1N-PISPO trans -Frame Gene of Sweet Potato Feathery

$494 \quad$ Mottle Potyvirus Is Produced during Virus Infection and Functions as an RNA

495 Silencing Suppressor. J Virol 90:3543-3557. 
13. Qin Y-H, Li X-C, Zhang Z-C, Qiao Q, Zhang D-S, Wang Y-J, Tian Y-T, Wang S. 2016. First Report of Sweet potato badnavirus A in China. Plant Dis 100:865.

14. Mbanzibwa DR, Tugume AK, Chiunga E, Mark D, Tairo FD. 2014. Small RNA deep sequencing-based detection and further evidence of DNA viruses infecting

15. Bhat A, Hohn T, Selvarajan R. 2016. Badnaviruses: The Current Global Scenario. Viruses 8:177.

16. Chabannes M, Iskra-Caruana M-L. 2013. Endogenous pararetroviruses-a reservoir 504 of virus infection in plants. Curr Opin Virol 3:615-620.

505 17. Li R, Salih S, Hurtt S. 2004. Detection of Geminiviruses in Sweetpotato by Polymerase Chain Reaction. Plant Dis 88:1347-1351.

18. Li F, Zuo R, Abad J, Xu D, Bao G, Li R. 2012. Simultaneous detection and differentiation of four closely related sweet potato potyviruses by a multiplex onestep RT-PCR. J Virol Methods 186:161-166.

510 19. Kyndt T, Quispe D, Zhai H, Jarret R, Ghislain M, Liu Q, Gheysen G, Kreuze JF.

511 2015. The genome of cultivated sweet potato contains Agrobacterium T-DNAs with

512 expressed genes: An example of a naturally transgenic food crop. Proc Natl Acad $513 \quad$ Sci 112:5844-5849.

514 20. Cuellar WJ, Tairo F, Kreuze JF, Valkonen JPT. 2008. Analysis of gene content in 515 Sweet potato chlorotic stunt virus RNA1 reveals the presence of p22 RNA silencing 
516 suppressor in only few isolates: implications to viral evolution and synergism. J Gen

$517 \quad$ Virol 89:573-582.

518 21. Sim J, Valverde R, Clark C, Chun S-C. 2008. Virus-like Particles and Cellular

519 Changes in Plants Infected with Sweetpotato Viruses. Plant Pathol J 24:36-45.

520 22. Roossinck MJ. 2015. Metagenomics of plant and fungal viruses reveals an

$521 \quad$ abundance of persistent lifestyles. Front Microbiol 5.

522 23. Roossinck MJ. 2011. The good viruses: viral mutualistic symbioses. Nat Rev

$523 \quad$ Microbiol 9:99-108.

524 24. Marquez LM, Redman RS, Rodriguez RJ, Roossinck MJ. 2007. A Virus in a Fungus

525 in a Plant: Three-Way Symbiosis Required for Thermal Tolerance. Science

$526 \quad 315: 513-515$.

527 25. Nakatsukasa-Akune M, Yamashita K, Shimoda Y, Uchiumi T, Abe M, Aoki T,

528 Kamizawa A, Ayabe S, Higashi S, Suzuki A. 2005. Suppression of Root Nodule

529 Formation by Artificial Expression of the TrEnodDRl (Coat Protein of White clover

$530 \quad$ cryptic virus 1 ) Gene in Lotus japonicus. Mol Plant Microbe Interact 18:1069-

$531 \quad 1080$.

532 26. Doyle JJ, Doyle JL. 1987. A rapid DNA isolation procedure for small quantities of 533 fresh leaf tissue. Phytochem Bull 19:11-19. 
534 27. Lodhi MA, Ye G-N, Weeden NF, Reisch BI. 1994. A simple and efficient method

535 for DNA extraction from grapevine cultivars andVitis species. Plant Mol Biol

$536 \quad$ Report 12:6-13.

537 28. Kumar S, Stecher G, Tamura K. 2016. MEGA7: Molecular Evolutionary Genetics

538 Analysis Version 7.0 for Bigger Datasets. Mol Biol Evol 33:1870-1874.

539 29. Weller SA, Elphinstone JG, Smith NC, Boonham N, Stead DE. 2000. Detection of

540 Ralstonia solanacearum strains with a quantitative, multiplex, real-time, fluorogenic

$541 \quad$ PCR (TaqMan) assay. Appl Environ Microbiol 66:2853-2858.

542 30. Livak KJ, Schmittgen TD. 2001. Analysis of Relative Gene Expression Data Using

543 Real-Time Quantitative PCR and the 2- $\Delta \Delta \mathrm{CT}$ Method. Methods 25:402-408. 
546 Fig 1. Genome structure of SPPV. Diagram depicting the genome structure of Sweet

547 potato pakakuy virus (SPPV). Circle indicates the genome with box arrows indicating the

548 locations of predicted open reading frames (ORFs) and numbered in order of occurrence.

549 Star and vertical black line indicate the location of the tRNA-met like region and short

550 stem-loop structure respectively, while the dotted line indicates location of a predicted

551 leader sequence.

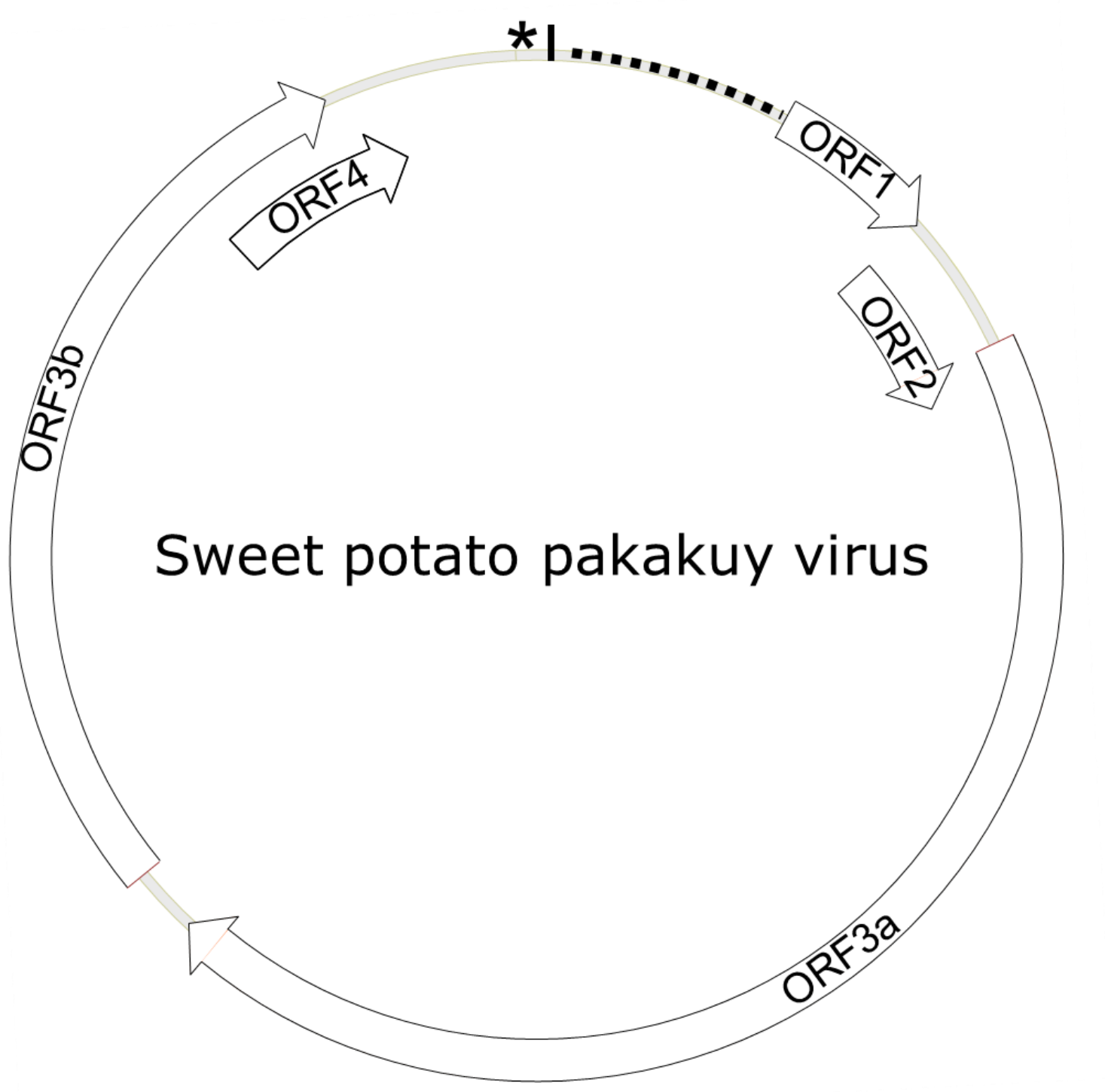




\section{Fig 2. Phylogenetic tree of SPPV sequences covering the Reverse transcriptase and}

554 RnaseH domains amplified from sweetpotato accessions from around the world. The

555 evolutionary history was inferred by using the Minimum Evolution methodand the

556 evolutionary distances were computed using the Maximum Composite Likelihood

557 method and are in the units of the number of base substitutions per site.. The optimal tree

558 with the sum of branch length $=1.15686856$ is shown. and is drawn to scale, with branch

559 lengths in the same units as those of the evolutionary distances used to infer the

560 phylogenetic tree. The percentage of trees in which the associated taxa clustered together

561 is shown next to the branches based on 500 bootstrap replications when larger than $70 \%$.

562 The ME tree was searched using the Close-Neighbor-Interchange (CNI) algorithm at a

563 search level of 1 . The Neighbor-joining algorithm was used to generate the initial tree.

564 The analysis involved 2o nucleotide sequences. All ambiguous positions were removed

565 for each sequence pair. There were a total of $828 \mathrm{nt}$ positions in the final dataset.

566 Evolutionary analyses were conducted in MEGA7 (28). Isolates are indicated by the

567 name of the variety from which they were amplified and the origin of the variety is

568 provided in brackets for each of them. BSMysV (Banana streak mysore virus) was used

569 as an outgroup for phylogenetic tree construction. Four phylogenetic groupings A, B, C

570 and D are highlighted in blue, red, green and yellow respectively. 
bioRxiv preprint doi: https://doi.org/10.1101/140517; this version posted May 21, 2017. The copyright holder for this preprint (which was not certified by peer review) is the author/funder, who has granted bioRxiv a license to display the preprint in perpetuity. It is made available under aCC-BY-NC 4.0 International license.

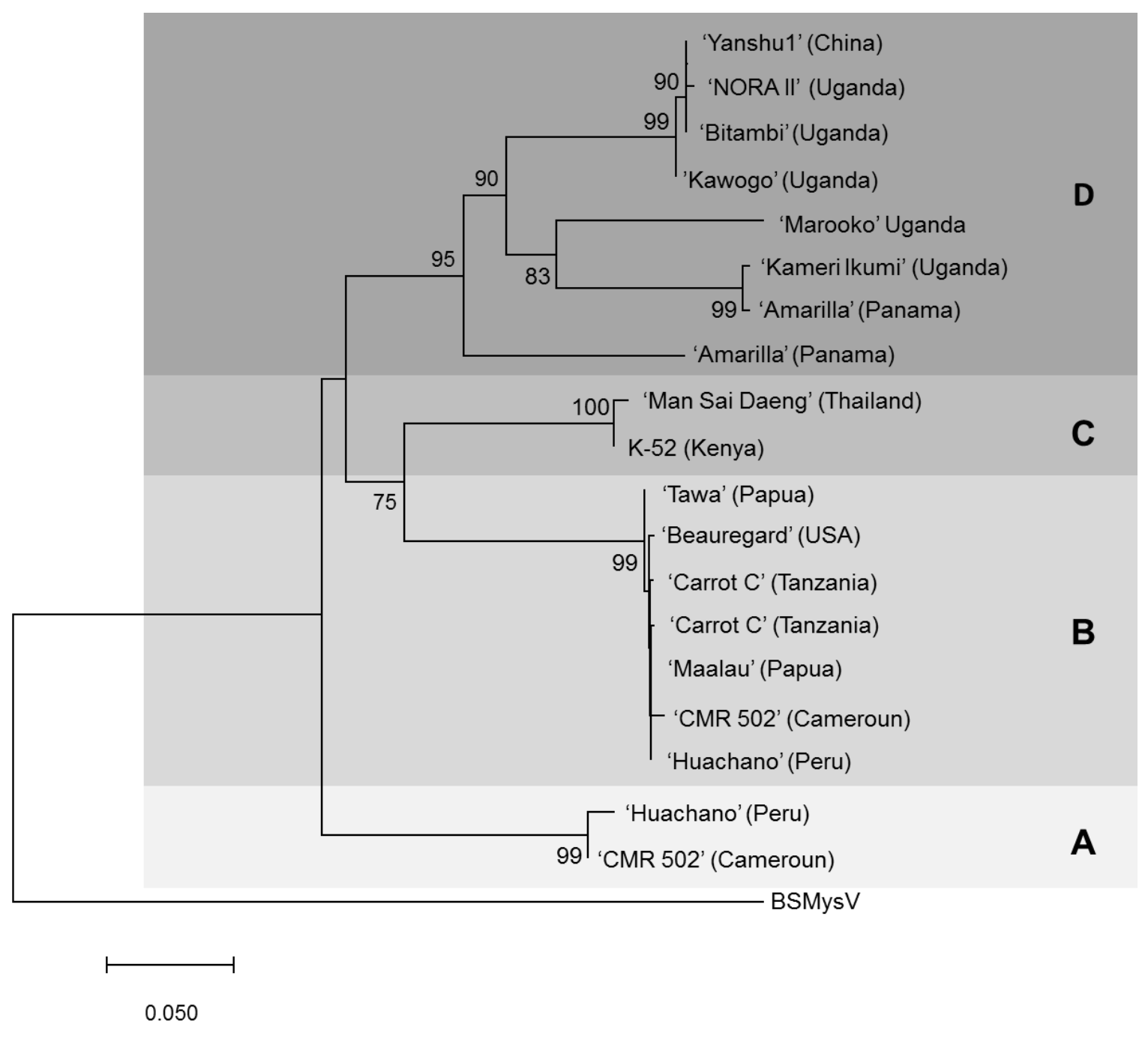


573 Fig 3. Southern blot of 'Huachano' DNA linearized with PstI and hybridized with a

574 probe corresponding to SPPV-B. From left to right, the first and third lanes contain 30

575 ug of sweetpotato (SP) DNA, and the second and fourth lanes contain $30 \mathrm{ug}$ of SP DNA

576 spikes with 30 and 15 pg of plasmid (containing SPPV-B DNA fragment corresponding

577 to the probe) respectivily corresponding to 1 or $1 / 2$ a copy per sweetpotato genome

578 equivalent; the $5^{\text {th }}$ and $7^{\text {th }}$ lanes are empty whereas the $6^{\text {th }}$ lane contatins 50 pg of SPPV-B

579 plasmid DNA and the last lane a DNA ladder.
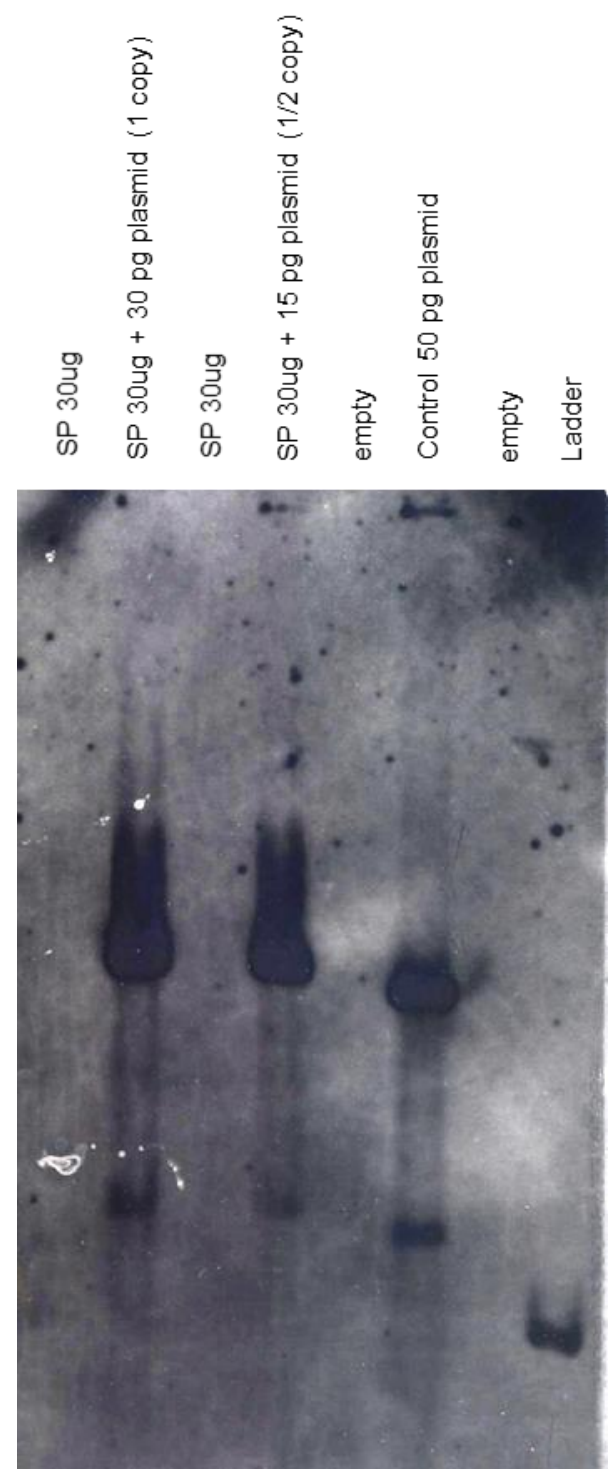
581 Fig 4. Relative expression for Badnavirus A and B. Graphic depicting the expression

582 of SPPV-A and SPPV-B in leaves in co-infection with SPFMV, SPCSV or both viruses

583 (SPVD) relative to a singly infected plants (healthy). * Significantly upregulated as

584 compared to singly infected plants (healthy; $\mathrm{p}=0.001$ )

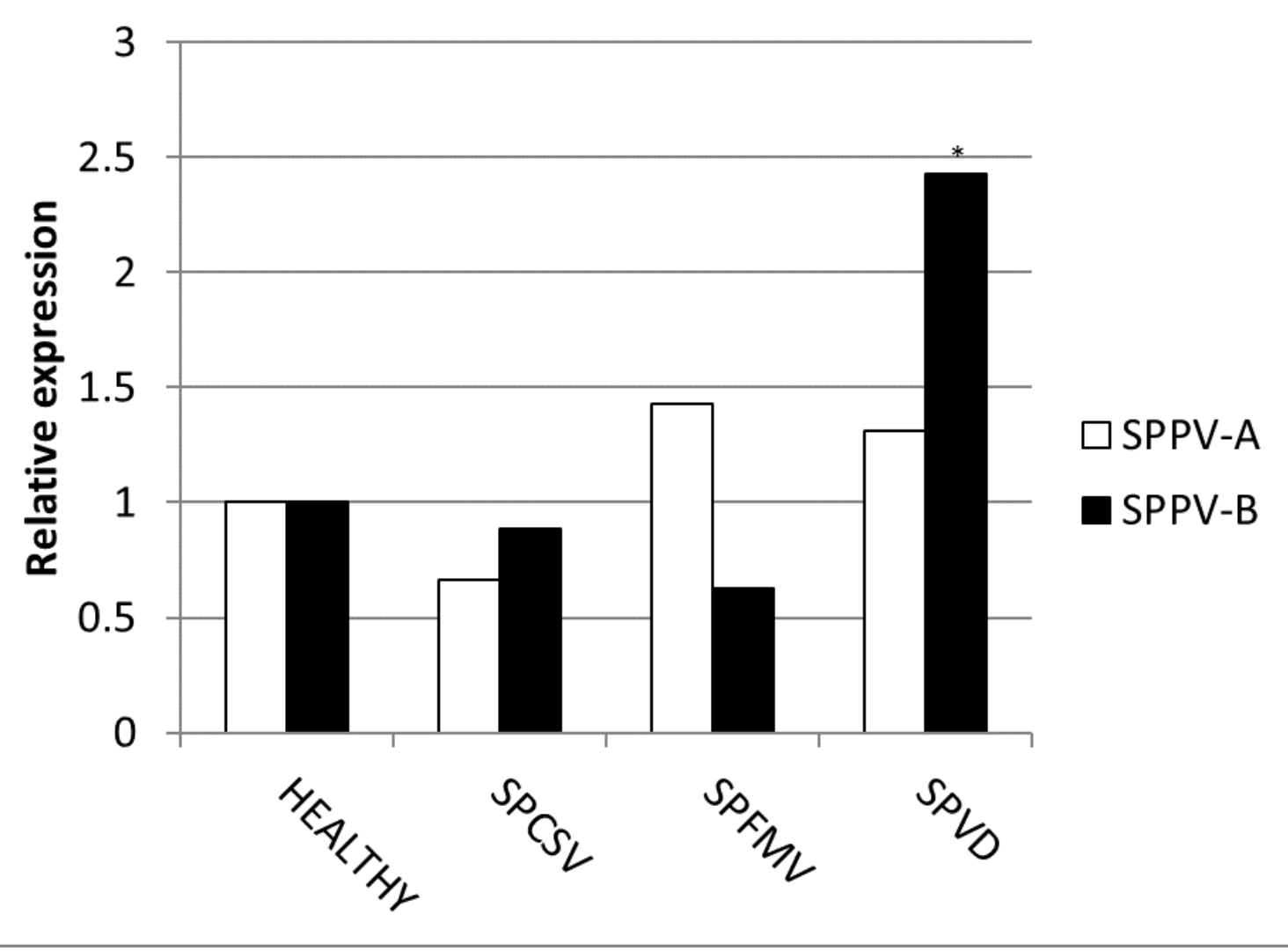


bioRxiv preprint doi: https://doi org/10.1101/140517; this version posted May 21, 2017. The copyright holder for this preprint (which was not certified by peer review) is the author/funder, who has granted bioRxiv a license to display the preprint in perpetuity. It is made available under aCC-BY-NC 4.0 International license.

587 Fig 5. Size and distribution and quantities of siRNAs targeting SPPV in sweetpotato

588 plants co infected with different viruses. A) Graphics show the normalized distribution

589 (per million siRNA reads sequenced) of siRNA covering the genomes of SPPV-A (left)

590 and -B (right) in healthy, SPFMV, SPCSV or dually (SPVD) co-infected plants.

591 Horizontal axis indicates the nucleotide position of the virus wheras the verticle axis

592 indicates the coverage of each nt position by siRNA sequences in sense (positive values)

593 and antisense (negative values) orientation. Lines in red, green, brown and blue represent

$59421,22,23$ and $24 \mathrm{nt}$ siRNAs respectivily.

595
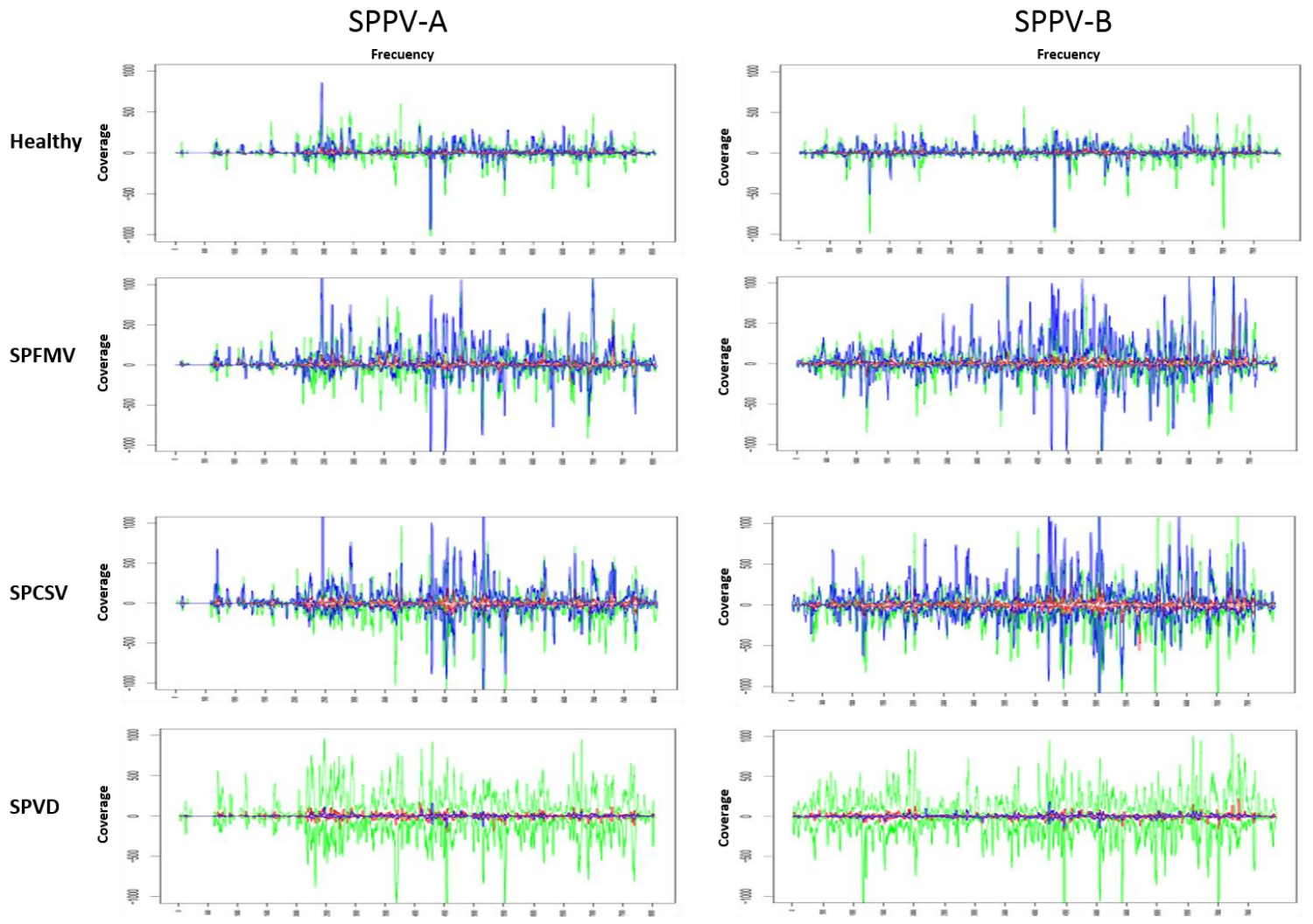

—Coverage 21nt —Coverage 22nt —Coverage 23nt —Coverage 24nt 
597 B) Bar graphics showing the normalized (per million siRNA reads sequenced) quantity

598 (vertical axis) and size (horizontal axis) of virus specific siRNAs in plants co-infected

599 with different viruses. Green, yellow, red and blue sections in the bars correspond to

600 SPPV-A, SPPV-B, SPFMV and SPCSV respectively.
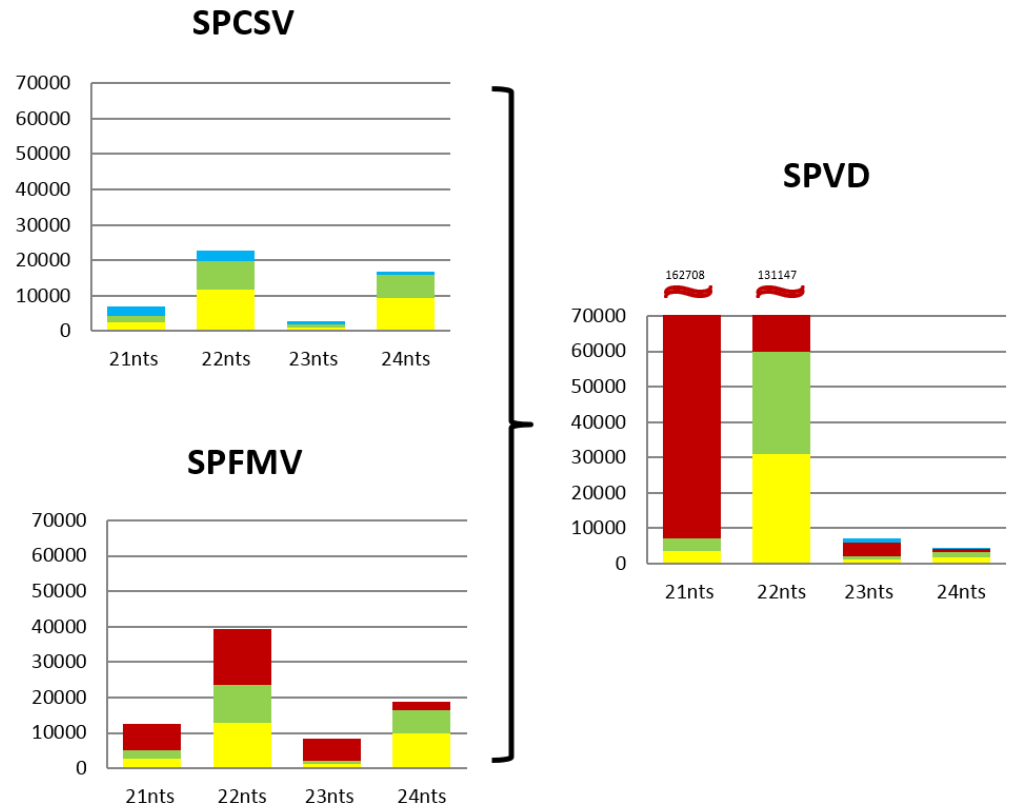

- SPCSV

- SPFMV

- SPPV-A

- SPPV-B

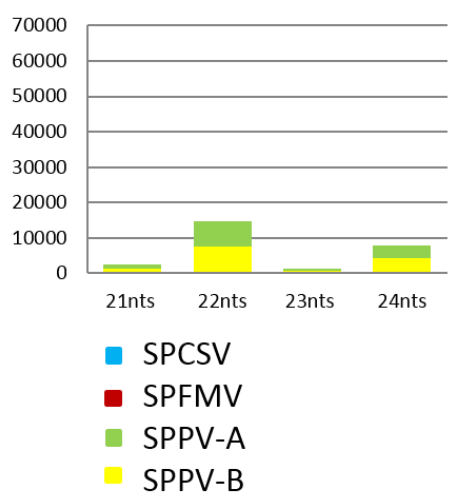


602 S1 Data. BLASTX results of contigs assembled from a mix of African sweetpotato

603 cultivars with similarity to SPPV. Contigs assembled from siRNA sequences of a bulk

604 sample including several African sweetpotato cultivars with similarity to Badnaviruses

605 (first sheet) and the hit table for each contig (sheet 2). 